\title{
KEEFEKTIFAN KALIMAT DALAM MAKALAH MAHASISWA NONREGULER PENDIDIKAN BAHASA DAN SASTRA INDONESIA FKIP UNTAN oleh Amriani Amir ${ }^{1}$
}

\begin{abstract}
Abstrak: Penelitian ini bertujuan mendeskripsikan keefektifan kalimat dalam makalah mahasiswa Program Nonreguler Pendidikan Bahasa dan Sastra Indonesia FKIP Untan ditinjau dari kehematan dan kesejajaran bentuk. Penelitian ini dilakukan di kampus FKIP Untan Jalan Ahmad Yani Pontianak. Metode yang digunakan adalah metode penelitian kualitatif yang diarahkan pada data kebahasaan. Sumber data penelitian ini adalah kalimat dalam makalah mahasiswa Program Nonreguler Pendidikan Bahasa dan Sastra Indonesia FKIP Untan. Pengambilan sampel dilakukan secara bertahap (multistage sampling). Data dianalisis melalui tahap identifikasi, klasifikasi, dan interpretasi. Hasil penelitian menunjukkan terdapat 44 kalimat yang tidak efektif dalam makalah ditinjau dari kehematannya meliputi kehematan kata, bentuk ganda, dan konjungsi. Terdapat 57 kalimat yang tidak efektif dalam makalah ditinjau dari kesejajaran bentuk, berupa kesejajaran unsur, pasangan konjungsi, dan kesejajaran penyusunan kalimat. Jadi, jumlah keseluruhan kalimat yang tidak efektif sebanyak 101 (49\%) kalimat dari 205 jumlah kalimat.
\end{abstract}

Kata Kunci: efektif, kalimat, kesejajaran, kehematan

\section{PENDAHULUAN}

Penggunaan bahasa Indonesia secara bertaat asas dapat ditunjukkan dalam berbagai bidang. Upaya peningkatan mutu dan pemasyarakatan penggunaan bahasa Indonesia hendaknya bukan hanya muncul pada slogan, melainkan segera ditindaklanjuti.

${ }^{l}$ Amriani Amir : adalah dosen Jurusan Pendidikan Bahasa dan Seni FKIP Untan 
Penggunaan bahasa Indonesia secara konsisten dalam berbagai keperluan dan bidang kehidupan akan memberikan kesan yang positif pada masyarakat atau bangsa. Dengan begitu, akan muncul rasa bangga memiliki bahasa Indonesia. Rasa bangga terhadap bahasa Indonesia akan bermuara pada rasa cinta tanah air, kebudayaan, nilai atau norma kehidupan masyarakat dan bangsa Indonesia.

Masyarakat Indonesia sangat beragam, baik dari suku, agama, adat istiadat maupun tingkat pendidikannya. Tingkat pendidikan merupakan salah satu faktor penentu perkembangan dan pelestarian penggunaan bahasa Indonesia yang bertaat asas.

Perguruan tinggi merupakan institusi tempat orang-orang yang bergelut dalam bidang akademik dengan tingkat pendidikan yang dapat dibanggakan. Setiap aktivitas yang terjadi di perguruan tinggi selalu berhubungan dengan bahasa. Penggunaan bahasa Indonesia pada masyarakat akademis hendaknya sesuai dengan posisinya sebagai masyarakat ilmiah yang harus menggunakan bahasa ilmiah termasuk dalam menyusun makalah.

Makalah merupakan salah satu bentuk karya ilmiah yang menggunakan bahasa ilmiah. Penggunaan bahasa Indonesia pada makalah diharapkan sudah mendekati kesempurnaan. Harapan tersebut timbul karena makalah adalah proses pembelajaran mahasiswa ketika akan membuat proposal penelitian dan skripsi.

Kemajuan penelitian bahasa Indonesia tidak lepas dari persoalan penggunaan kalimat. Penggunaan kalimat yang terdapat dalam karya tulis ilmiah menggambarkan kemajuan penelitian bahasa. Penelitian ini dilakukan untuk mendapatkan gambaran penggunaan kalimat efektif dalam makalah mahasiswa nonreguler Pendidikan Bahasa dan Sastra Indonesia.

Penelitian untuk mengungkap keefektifan kalimat dalam makalah mahasiwa non reguler dirasakan perlu setelah diadakan pengamatan sementara dan ditemukan beberapa gejala kalimat yang kurang efektif. Gejala yang dimaksud yaitu adanya penggunaan kata/kalimat yang berlebihan, penggunaan kata yang tidak tepat, penempatan konjungsi di awal kalimat, paragraf yang hanya terdiri atas satu kalimat yang diawali dengan konjungsi, kalimat yang tidak memiliki subjek, pelesapan subjek yang tidak tepat dan peletakan angka pada awal kalimat. Gejala-gejala tersebut kemungkinan banyak terjadi sehingga menarik untuk diteliti lebih lanjut. 
Penelitian ini difokuskan pada kehematan dan kesejajaran bentuk. Kehematan dan kesejajaran bentuk merupakan ciri kalimat efektif. Kehematan dan kesejajaran bentuk diangkat dalam penelitian ini karena dari beberapa gejala yang terkumpul, penyimpangan yang banyak ditemukan berupa penyimpangan kaidah kehematan dan kesejajaran sehingga dipandang perlu mendapat perhatian serius khususnya dosen bahasa Indonesia.

Penelitian ini dibatasi pada keefektifan kalimat dalam makalah mahasiswa non reguler Pendidikan Bahasa dan Sastra Indonesia FKIP Untan. Kalimat efektif sangat luas kajiannya, mencakup keutuhan, kesejajaran, pemokusan, kehematan, dan variasi. Penelitian ini dibatasi pada kalimat efektif ditinjau dari kehematan dan kesejajaran bentuk. Tujuan penelitian ini yaitu mendeskripsikan keefektifan kalimat dalam makalah mahasiswa non reguler Pendidikan Bahasa dan Sastra Indonesia FKIP Untan ditinjau dari kehematannya dan mendeskripsikan keefektifan kalimat dalam makalah mahasiswa

non reguler Pendidikan Bahasa dan Sastra Indonesia FKIP Untan ditinjau dari kesejajarannya.

\section{TINJAUAN PUSTAKA}

Darwis (2002:10) memaparkan bahwa bahasa Indonesia akan menghadapi masalah dengan hadirnya bahasa Inggris sebagai bahasa yang berprestise tinggi seperti yang telah terjadi di Filipina, Malaysia dan India.

Lebih lanjut, Dardjowidjojo (dalam Darwis, 2002:10) menjelaskan posisi bahasa Inggris di Asia. Bahasa Tagalog diperjuangkan menjadi bahasa nasional di Filipina, tetapi tidak terwujud sebagaimana mestinya. Bahasa Tagalog hanya menjadi salah satu dari dua bahasa resmi, kehadiran bahasa Inggris berpengaruh besar di negara tersebut. Bahasa Inggris juga terus membayangi peranan bahasa Melayu seperti yang terjadi di Malaysia, diperkuat dengan diizinkannya bahasa Inggris digunakan sebagai bahasa pengantar di perguruan tinggi pada tahun 1993 oleh Perdana Menteri Malaysia. Demikian juga yang terjadi di India, bahasa Hindu [sic] merupakan bahasa resmi, tetapi dari tahun ke tahun bahasa Inggris terus mengalami penguatan dan perluasan penggunaan.

Bangsa Indonesia bertanggung jawab melestarikan dan menggunakan bahasa Indonesia sebagaimana mestinya. Sebenarnya bahasa itu mempunyai sifat netral. Sama halnya dengan pisau, ia dapat digunakan untuk tujuan- 
tujuan yang berguna dan dapat pula digunakan untuk mencelakakan orang lain. Pisau yang berada di tangan seorang dokter ahli bedah berbeda dengan pisau yang sama apabila berada di tangan seorang penodong. Demikian halnya bahasa dapat digunakan untuk memperkuat semangat atau ikatan persatuan dan dapat pula digunakan untuk mengoyak-ngoyak persatuan itu sendiri. Bahasa dapat digunakan sebagai sarana penyampaian ekspresi kedamaian dan dapat pula digunakan sebagai sarana penyampaian ekspresi kebencian. Bahasa dapat digunakan untuk menjelaskan pikiran dan dapat pula digunakan untuk mengaburkan atau menutup-nutupi pikiran atau realitas. Jadi, segalanya terpulang kepada niat atau iktikat siapa yang berdiri di belakang bahasa." (Darwis, 2002:1)

Darwis (2002:9) mengungkapkan bahwa tahun-tahun terakhir ini semakin banyak karya ilmiah, terutama tesis dan disertasi yang ditulis dalam bahasa Indonesia meskipun ada beberapa disertasi yang ditulis dalam bahasa Inggris. Hal ini menunjukkan bahasa Indonesia mampu menjadi bahasa ilmu pengetahuan. Namun, hal yang memprihatinkan adalah gejala rendahnya kemampuan dalam menyusun dan menggunakan kalimat efektif dalam karya ilmiah yang ditulis dalam bahasa Indonesia.

\section{A. Ragam Bahasa}

Nababan (1991: 14) mengemukakan bahwa perbedaan-perbedaan bahasa menghasilkan ragam-ragam bahasa yang disebut dengan istilah-istilah yang berlainan (1) Ragam bahasa yang sehubungan dengan situasi bahasa atau letak geografis yang disebut dialek, (2) ragam bahasa yang sehubungan dengan situasi bahasa atau tingkat formalitas disebut fungsiolek, (3) ragam bahasa yang dihasilkan oleh perubahan bahasa sehubungan dengan perkembangan waktu, maka ragam tersebut dapat kita sebut ragam itu secara kronolek. Dittman (dalam Halim, 1979: 93), mengatakan bahwa ragam bahasa dapat dikelompokkan ke dalam empat bagian, yaitu:(1) ragam baku, (2) ragam daerah, (3) ragam sosial, dan (4) ragam fungsional. Untuk lebih jelasnya bahwa ragam baku adalah ragam bahasa yang dikembangkan dan diakui oleh sebagian besar warga masyarakat pemakainya sebagai kerangka rujukan norma bahasa. Ragam daerah adalah ragam bahasa yang norma dan kaidahnya berlangsung secara terbatas. Ragam sosial adalah ragam sebagian besar norma dan kaidahnya didasarkan atas kesepakatan bersama dalam 
lingkungan sosial, sedangkan ragam fungsional adalah ragam bahasa yang berkaitan dengan profesi, lembaga dan lingkungan kerja.

Menurut anggapan Suwito (1983: 148), ragam bahasa adalah suatu istilah yang digunakan untuk menunjukkan salah satu dari sekian banyak variasi yang terdapat dalam pemakaian bahasa. Variasi ini timbul karena adanya kebutuhan penutur akan alat komunikasi yang sesuai dengan situasi dan konteks sosialnya. Adanya berbagai variasi menunjukkan bahwa pemakai bahasa (tutur) bersifat aneka ragam (heterogen), sedangkan menurut Moeliono (1989: 142) ragam bahasa adalah bentuk bahasa yang digunakan untuk menyampaikan makna sosial atau makna yang artistik.

Nababan (1984: 22) mengemukakan ada lima tingkat gaya yang digunakan dalam berbahasa Indonesia yaitu (1) Ragam beku (frozen), (2) Ragam resmi (formal), (3) ragam usaha (consultative), (4) ragam santai (casual) adalah ragam bahasa santai antarteman dalam berbincang-bincang, rekreasi, berolah raga dan sebagainya, (5) ragam akrab. Lebih lanjut, Nababan (1984:23) menjelaskan jika pasangan-pasangan kalimat di bawah ini dibandingkan akan terlihat kalimat-kalimat itu tidaklah tergolong ragam (tingkat) bahasa yang sama.

a. Bapak Suparman menerangkan makna peristiwa itu.

b. Pak Parman terangkan arti kejadian itu

Jika kedua kalimat itu ditempatkan, kalimat (a) akan ditempatkan pada tingkat yang lebih tinggi dari (b). Kalimat (a) ragam formal sedangkan (b) ragam usaha.

a. Saya tidak mengerti maksud saudara

b. Aku tak ngerti maksudmu

c. Nggak ngerti

Kalimat (a) lebih tinggi tingkatnya dari (b) dan (b) lebih tinggi tingkatnya dari (c). Kalimat (a) disebut ragam usaha karena ragam ini yang digunakan sehari-hari dalam pekerjaan. Kalimat (b) ialah ragam yang digunakan antarteman dalam keadaan bersantai; Kalimat (c) ialah ragam akrab, yang dapat digunakan antara orang sebaya dalam keluarga atau teman yang akrab.

Menurut Nababan (1984:24), perbedaan-perbedaan di antara kelima ragam ini yaitu perbedaan pilihan kata, perbedaan bentuk kata (morfologi) dan perbedaan bentuk kalimat keseluruhannya (sintaksis). Terlihat juga 
adanya perbedaan-perbedaan yang jelas dalam intonasi kalimat dan keseluruhan gaya orangnya (behavior).

Adapun skema ragam bahasa dikemukakan oleh Sugono (1997: 10) sebagai berikut

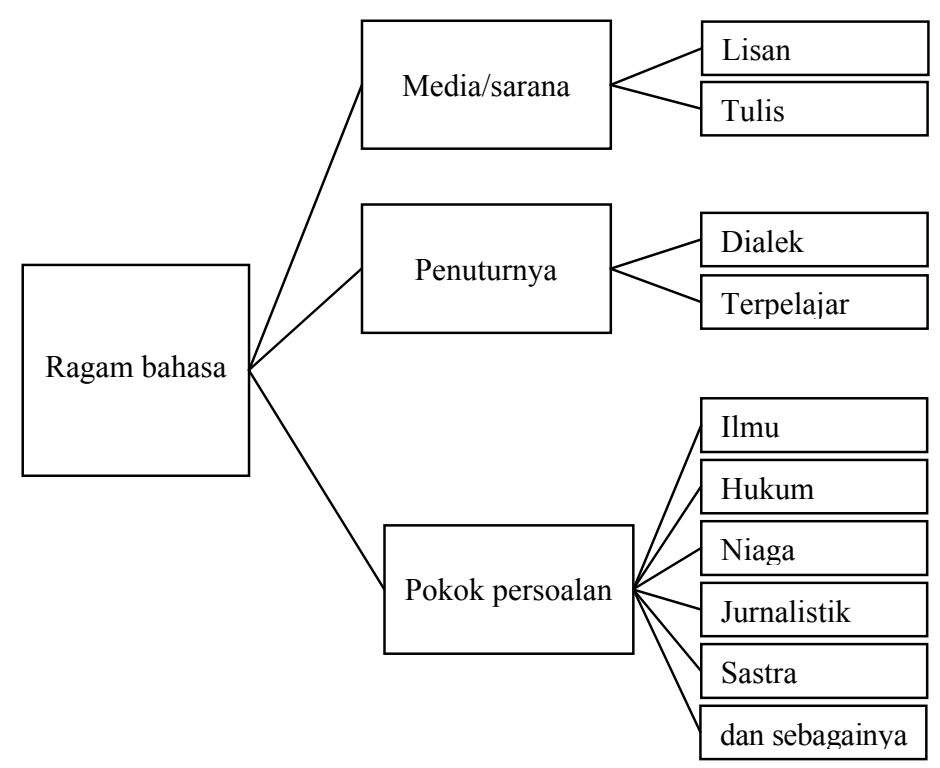

Sugono (1997:11), menyimpulkan tiga kriteria penting tentang ragam bahasa yaitu media yang digunakan, latar belakang penutur, dan pokok persoalan yang dibicarakan.

Berdasarkan penelusuran dari beberapa buku yang berhubungan dengan ragam bahasa dan ujaran lisan Maknun, ada empat kriteria penting yang perlu diperhatikan pada persoalan ragam bahasa. Dapat dilihat pada skema berikut: 


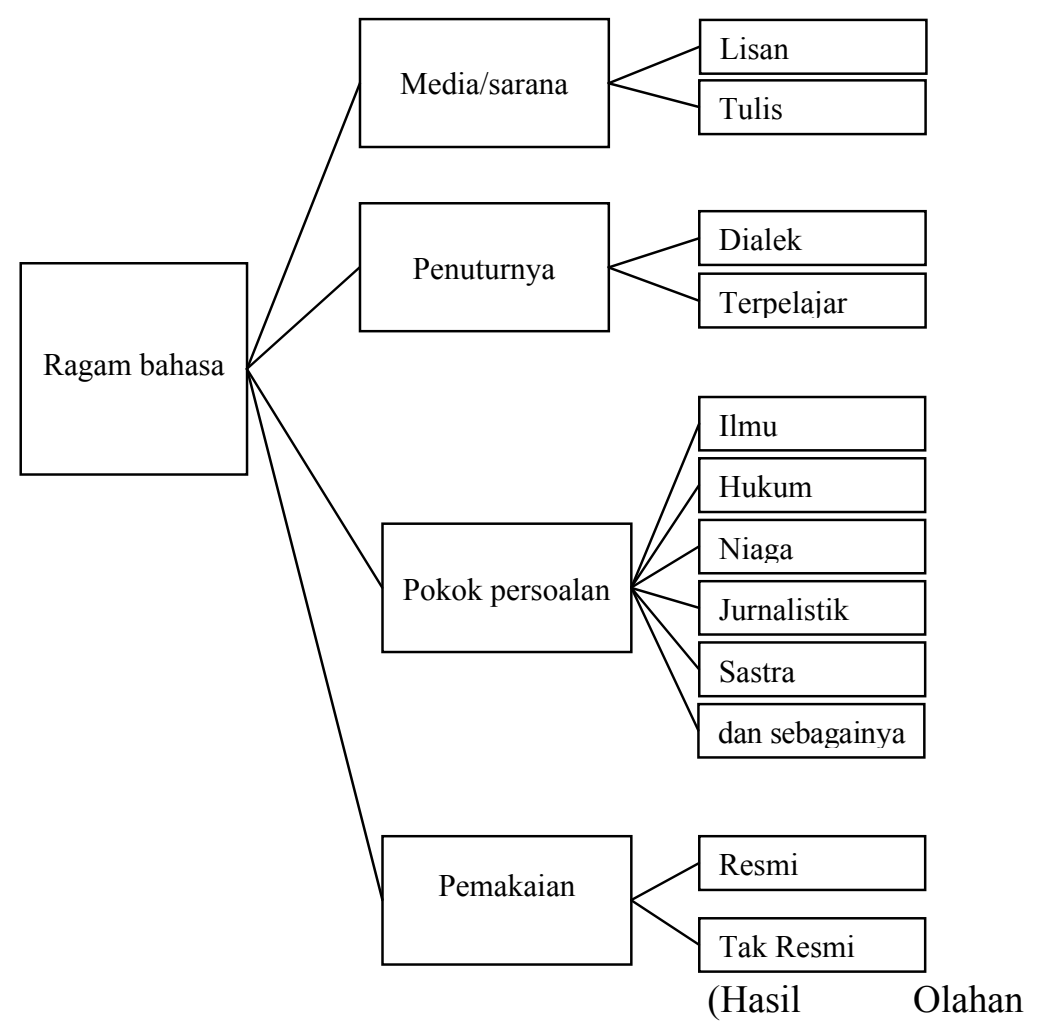

Penulis)

Jadi, ragam bahasa adalah variasi-variasi bahasa yang dapat ditemukan melalui karakteristik bahasa tiap kelompok masyarakat, dan menjadi ciri pembeda dari kelompok pengguna bahasa yang lain.

\section{Bahasa Ilmiah}

Ciri bahasa ilmiah ada tujuh, yaitu:(a) bernada formal, bernalar, dan objektif, (b) penyampaian gagasan lugas, jelas, ringkas, tepat, dan tidak ambigu, (c) umumnya menggunakan bentuk pasif dan tidak menggunakan kata ganti persona tunggal maupun jamak, (d) hemat, (e) berbentuk prosa eksposisi, (f) kalimat dan paragraf tidak terlalu panjang, dan (g) format penulisannya konsisten (Pedoman Penulisan Tesis dan Disertasi, 2004:31)

Ciri umum bahasa ilmiah menurut Hertzler (dalam Hastuti, 2003:92-93), yaitu:(a) tegas (zakelijk) dan cermat, menghindari sifat-sifat ketaksaan dan kesamaran, (b) objektif dan tidak perorangan, (c) lebih rasional dan menjauhkan segala pertimbangan-pertimbangan yang bersifat emosional 
dalam penafsirannya, (d) bersifat eksak, lepas dari bidang seni dan budaya yang mementingkan nilai konotasi, sindiran, metafora, perumpamaan) karena tinjauannya berdasarkan makna yang tetap, (e) lebih cenderung pada pembakuan makna kata, ungkapan, maupun gaya, (f) tidak meluap-luap, datar, ekonomis, padat, dan padu serta tidak bermain kata-kata, dan (g) kata dan istilahnya lebih mantap, umumnya tetap jika dilihat segi perkembangan bahasanya.

Menurut Moeliono (1998: 161), ciri khas laras bahasa keilmuan ada lima yaitu:(a) cendekia, teliti dan objektif (b) hubungan dan fungsi sintaksisnya nyata, (c) paragrafnya berpautan dan kalimatnya bertalian, (d) istilah yang digunakan tidak ambigu, dan (e) diksi yang serasi, cermat, dan tepat.

\section{Kalimat Efektif}

Menurut Darwis (2004:3), sejauh ini terlihat dengan nyata bahwa kemampuan menggunakan atau menyusun kalimat efektif dalam karya tulis penelitian masih sangat rendah. Terdapatnya kalimat yang tidak bernalar, baik karena struktur atau susunannya yang tidak sesuai dengan kaidah-kaidah ketatabahasaan maupun karena diksi atau pilihan kata yang tidak tepat bahkan terdapat pula gejala-gejala kesalahan ejaan.

Arifin (1987:85) mengungkapkan bahwa kalimat efektif yaitu kalimat yang jelas, sesuai kaidah, ringkas, dan mudah dibaca. Selanjutnya, dipaparkan beberapa ketentuan kalimat efektif yaitu subjek tidak didahului preposisi, tidak terdapat subjek yang ganda, kata sedangkan dan sehingga tidak digunakan dalam kalimat tunggal, predikat kalimat tidak didahului kata yang, unsur rincian sejajar atau paralel, tidak terjadi pengulangan subjek, subjek yang tidak sama dalam induk kalimat dan dalam anak kalimat harus eksplisit, konjungsi penanda anak kalimat dinyatakan secara eksplisit, pemakaian kata hemat, urutan kata tepat, predikat-objek tidak tersisipi, tidak menggunakan konjungsi yang bertentangan.

Akhadiah dkk. (1996:116) mengatakan agar kalimat yang disampaikan dapat mengenai sasaran yang diharapkan, perlu diperhatikan ciri-ciri kalimat efektif yaitu:(1) kesepadanan dan kesatuan, (2) kesejajaran bentuk, (3) penekanan, (4) kehematan dalam mempergunakan kata, dan (5) kevariasian dalam struktur kalimat. Sejalan dengan pendapat tersebut, 
Moeliono (1998:162) Mengungkapkan ciri kalimat efektif yaitu:(1) keutuhan ditandai dengan kesatuan logika yang berkaitan, (2) perpautan dengan memperhatikan penggunaan kata ganti, kesejajaran gagasan dan isi kalimat tetap dipertahankan meskipun sudut padang berbeda, (3) penempatan fokus, dan (4) kehematan.

Alwi (2001:40-48) memaparkan mengenai kalimat efektif disertai pembahasan dengan contohnya masing-masing dan menjadi landasan dalam penelitian ini. Kalimat efektif adalah kalimat yang maksud dan isinya tersampaikan secara lengkap kepada pembaca/lawan tutur karena adanya kesepahaman yang sama antara penulis/si penutur dan pembaca/lawan tutur. Hal itu terjadi karena kalimat tersebut memiliki ciri antara lain keutuhan, kesejajaran, pemokusan, penghematan, dan variasi.

\section{METODE PENELITIAN}

Penelitian ini adalah penelitian kualitatif yang diarahkan pada data kebahasaan yang terdapat dalam penggunaan kalimat bahasa Indonesia dengan mengkhususkan pada keefektifan kalimat yang meliputi kehematan dan kesejajaran bentuk dengan menggunakan pendekatan bahasa Indonesia ragam ilmiah. Lokasi penelitian ini yaitu lingkungan FKIP Untan khususnya Program Studi Non reguler Pendidikan Bahasa dan Sastra Indonesia terletak di Jalan Ahmad Yani kampus Universitas Tanjungpura Pontianak.

\section{Sumber Data}

Data penelitian ini diambil dari naskah makalah mahasiswa Non reguler Pendidikan Bahasa dan Sastra Indonesia berupa data tulis. Data tersebut merupakan data primer, sedangkan buku-buku yang relevan dengan penelitian ini merupakan data sekunder.

\section{Populasi dan Sampel}

Populasi dalam penelitian ini adalah semua kalimat yang terdapat dalam naskah makalah mahasiswa Nonreguler Pendidikan Bahasa dan Sastra Indonesia. Sampel dalam penelitian ini ada dua, yaitu sampel sumber data dan sampel data. Sampel sumber data berupa naskah makalah sebanyak 40 dengan cara mengambil 20 dari mahasiswa tingkat rendah dan 20 mahasiswa tingkat atas. Sampel data berupa kalimat yang diteliti dalam naskah makalah dan tugas terstrukur dengan mengambil dua sampai lima kalimat yang berasal 
dari sampel sumber data sesuai tipe yang dianalisis dan jumlahnya sesuai kebutuhan.

\section{Teknik Pengumpulan Data}

Teknik penarikan sampel sumber data dilakukan dengan random yaitu semua sampel sumber data memiliki peluang terpilih menjadi sampel data, sedangkan teknik penarikan sampel data dilakukan secara purposive. Teknik ini dilakukan untuk memperoleh data sesuai dengan kajian dalam penelitian ini. Penelitian ini menggunakan teknik sampel probabilitas secara multistage sampling yaitu penarikan sampel secara bertahap dalam dua atau lebih tahapan. Teknik pengumpulan data meliputi teknik observasi, teknik catat, dan evaluasi.

\section{Teknik Analisis Data}

Penelitian ini dilakukan untuk memperoleh data penggunaan kalimat efektif dalam naskah makalah khususnya kehematan dan penggunaan konjungsi dalam kalimat. Setelah data terkumpul, langkah selanjutnya dianalisis melalui tahap:

a. identifikasi, mengidentifikasi kalimat dalam naskah makalah mahasiswa Non reguler Pendidikan Bahasa dan Sastra Indonesia sesuai penelitian.

b. klasifikasi/kategorisasi, mengklasifikasi data yang telah ditemukan sesuai dengan persamaannya

c. interpretasi, menginterpretasi data yang memungkinkan lahirnya teori

\section{PEMBAHASAN}

Berdasarkan penelitian yang dilakukan pada makalah mahasiswa nonreguler bahasa Indonesia, ditemukan beberapa kalimat yang kurang efektif ditinjau dari segi kesejajaran bentuk dan kehematan. Data kesejajaran dan kehematan ditampilkan dalam pembahasan ini karena tampilan data ini menjadi gambaran penggunaan kalimat pada beberapa makalah yang membutuhkan perhatian pemerhati bahasa.

Data penelitian ini ditinjau kesejajarannya meliputi kesejajaran unsur, kesejajaran pasangan konjungsi, dan kesejajaran penyusunan kalimat. Data penelitian ditinjau kehematannya meliputi penggunaan kata dan kalimat yang berlebihan, penggunaan bentuk ganda, dan penggunaan konjungsi yang serentak. 


\section{A. Kesejajaran Bentuk}

\section{Kesejajaran Pasangan Konjungsi}

\section{a.Pasangan bukan-melainkan}

Penggunaan pasangan bukan-melainkan, tidak-tetapi sering dipertukarkan menjadi bukan-tetapi atau tidak-melainkan seperti pada kalimat berikut. Lazimnya penggunaan pasangan ini membuat penggunaan bahasa tidak menyadari kekeliruannya. Penggunaan pasangan ini jumlahnya hampir berimbang, menunjukkan masih kurangnya pemahaman pengguna bahasa.

\section{Data (1)}

Dalam proses evaluasi pembelajaran, guru abad 21 bukan hanya mengevaluasi dari hasil uji siswa, tetapi juga mengevaluasi keaktifan siswa dalam proses pembelajaran.

\section{Data (2)}

Alat evaluasi juga disusun bukan hanya mengukur skala kemampuan siswa pada tahap ingatan, tetapi harus sampai pada tingkat pemahaman siswa.

\section{Data (3)}

Esei argumentasi, yakni esei yang bukan hanya menunjukkan fakta, tetapi juga menunjukkan permasalahannya kemudian menganalisisnya dan mengambil suatu kesimpulan dari padanya.

\section{Data (4)}

Tujuan kritik bukan hanya menunjukkan keunggulan, kelemahan, benar dan salahnya sebuah karya sastra dipandang dari sudut tertentu, tetapi tujuan akhirnya adalah mendorong sastrawan untuk mencapai penciptaan sastra setinggi mungkin dan juga mendorong pembaca untuk mengapresiasi karya sastra secara lebih baik.

\section{Data (5)}

Pengembangan dan pemanfaatan bukan saja untuk kehidupan masa lampau, tetapi juga bisa dirasakan hingga masa sekarang ini, walaupun tidak begitu kentara.

Konjungsi tetapi dan melainkan mempunyai fungsi yang sama tetapi apabila pasangannya dipertukarkan, kalimat tersebut menjadi tidak efektif karena kata tidak dan bukan posisinya berbeda pada kalimat tertentu, seperti "Dia tidak guru". Kalimat tersebut terasa aneh sebab pengingkaran tidak pada kalimat tersebut tidak tepat. Bandingkan dengan 
kalimat "Dia bukan guru". Kalimat tersebut lebih mudah dipahami dibandingkan kalimat "Dia tidak guru".

Penggunaan pasangan kata bukan-melainkan sebaiknya dapat dilihat pada kalimat berikut.

\section{Kalimat}

Dalam proses evaluasi pembelajaran, guru abad 21 bukan hanya mengevaluasi hasil uji siswa, melainkan juga mengevaluasi keaktifan siswa dalam proses pembelajaran.

\section{Kalimat}

Alat evaluasi juga disusun bukan hanya mengukur skala kemampuan siswa pada tahap ingatan, melainkan harus sampai pada tingkat pemahaman siswa.

\section{b.Pasangan tidak-tetapi}

Kalimat berikut memperlihatkan pasangan tidak-melainkan yang seharusnya tidak-tetapi. Kalimat tersebut menjadi tidak efektif apabila pasangannya dipertukarkan karena menyalahi kaidah kesejajaran.

\section{Data (6)}

Mereka tidak ingin menyusun secara apriori beberapa teori yang berlaku umum, melainkan berdasarkan sejumlah analisa pada beberapa prinsip yang berlaku sementara saja.

\section{Data (7)}

Keterkaitan ini memiliki arti bahwa prestasi peserta didik tidak hanya ditentukan oleh apa yang mereka lakukan di lingkungan sekolah, melainkan prestasi peserta didik juga ditentukan oleh apa yang mereka kerjakan di dunia kerja dan di masyarakat pada umumnya.

\section{Data (8)}

Mata pelajaran dan mata kuliah yang dikembangkan tidak lagi bersifat monolitik melainkan lebih banyak yang bersifat integratif.

\section{Data (9)}

Implikasi dari pendidikan berwawasan global menurut perspektif reformasi tidak hanya bersifat perombakan kurikulum, melainkan juga merombak sistem, struktur dan proses pendidikan.

\section{Data (10)}

Bersifat sistemik-organik berarti sekolah merupakan sekumpulan proses yang bersifat interaktif yang tidak dapat dilihat sebagai hitam-putih, 
melainkan setiap interaksi harus dilihat sebagai satu bagian dari keseluruhan interaksi yang ada.

\section{Data (11)}

Berdasarkan perspektif reformasi, pendidikan berwawasan global menuntut kebijakan pendidikan tidak semata sebagai kebijakan sosial, melainkan suatu kebijakan yang berada di antara kebijakan sosial dan kebijakan yang mendasarkan mekanisme pasar.

Kalimat (6)-(11) menjadi tidak efektif apabila pasangannya dipertukarkan, karena kata tidak dan bukan posisinya berbeda pada kalimat tertentu, seperti Parto bukan memukul kucing. Kalimat tersebut terdengar janggal sebab pengingkaran bukan pada kalimat tersebut tidak tepat. Bandingkan dengan kalimat Parto tidak memukul kucing. Kalimat tersebut lebih mudah dipahami dibandingkan dengan kalimat Parto bukan memukul kucing. Penggunaan pengingkaran tidak lebih tepat mendahului predikat berupa kata kerja, sedangkan bukan lebih tepat mendahului kata benda seperti pada kalimat Yuli bukan penyiar radio melainkan dosen. Penggunaan pasangan kata, tidak-tetapi sebaiknya dapat dilihat pada kalimat berikut.

\section{Kalimat}

Mereka tidak ingin menyusun secara apriori beberapa teori yang berlaku umum, tetapi berdasarkan sejumlah analisis beberapa prinsip yang berlaku sementara saja.

\section{Kalimat}

Keterkaitan ini memiliki arti bahwa prestasi peserta didik tidak hanya ditentukan oleh yang dilakukannya di lingkungan sekolah, tetapi prestasi peserta didik juga ditentukan oleh yang dikerjakannya di dunia kerja dan di masyarakat pada umumnya.

\section{c. Pasangan baik-maupun}

Kalimat berikut memperlihatkan pasangan baik-ataupun seharusnya baik-maupun. Kalimat tersebut menjadi tidak efektif apabila pasangannya dipertukarkan karena menyalahi kaidah kesejajaran.

\section{Data (12)}

Hasilnya berupa kapabilitas, baik berupa pengetahuan, sikap ataupun keterampilan tertentu.

\section{Data (13)}


Dalam tradisi sastra Melayu lama, prosa adalah seluruh hasil karya sastra lisan dan tulisan yang panjang, baik yang berbentuk cerita ataupun bukan cerita, dengan bahasa Melayu sebagai medium.

\section{Data (14)}

Puisi Dramatik pada dasarnya berisi analisis watak seseorang baik bersifat historis, mitos ataupun fiktif ciptaan penyair.

Kalimat (12)-(14) memperlihatkan pasangan konjungsi baik-ataupun. Kaidah penulisan tidak tidak membenarkan penggunaan konjungsi tersebut sebagai pasangan dalam merangkaikan kalimat. Penggunaan pasangan kata, baik-maupun sebaiknya dapat dilihat pada kalimat berikut.

\section{Kalimat}

Hasilnya berupa kapabilitas, baik berupa pengetahuan, sikap maupun keterampilan tertentu

\section{d. Pasangan antara-dan}

Kalimat berikut memperlihatkan pasangan antara-dengan seharusnya antara-dan. Kalimat tersebut menjadi tidak efektif apabila pasangannya dipertukarkan karena menyalahi kaidah kesejajaran.

\section{Data (15)}

Dialog ialah cakapan antara seorang tokoh dengan banyak tokoh. duolog ialah cakapan antara dua tokoh saja.

\section{Data (16)}

Bagi Jasus kemunculan bahasa bukan dari interaksi individu dengan obyek, tapi interaksi antara individu dengan individu yang lain.

\section{Data (17)}

Pendidikan selalu menghadapi masalah, karena selalu terdapat kesenjangan antara apa yang diharapkan dengan hasil yang dapat di capai dari proses pendidikan.

\section{Data (18)}

Antara sastrawan yang satu dengan sastrawan yang lain jelas juga memiliki batasan yang berbeda.

Data (15)-(18) memperlihatkan pasangan konjungsi antara-dengan. Kaidah penulisan tidak membenarkan penggunaan konjungsi tersebut sebagai pasangan dalam merangkai kalimat. Penggunaan pasangan kata, antara-dan sebaiknya dapat dilihat pada kalimat berikut. 


\section{Kalimat}

Dialog ialah cakapan antara seorang tokoh dan banyak tokoh, duolog ialah cakapan antara dua tokoh saja.

\section{Kesejajaran Penyusunan Kalimat yang Ditandai Konjungsi}

\section{a. Konjungsi sedangkan}

Penggunaan konjungsi sedangkan digunakan pada kalimat majemuk hubungan pertentangan. Susunan kalimat berikut dipenggal sehingga menjadi kalimat yang tak lengkap. Kalimat yang diawali dengan konjungsi masih berhubungan dengan kalimat sebelumnya.

\section{Data (19)}

Sedangkan untuk melakukan penelitian terhadap teater rakyat dapat menggunakan metodologi kajian tradisi lisan.

\section{Data (20)}

Sedangkan sesuai dengan genrenya, sastra elektronik dapat dijabarkan ke dalam sub-sub genre seperti di bawah ini.

\section{Data (30)}

Sedangkan non imajinatif adalah kebalikan dari imajinatif yaitu tidak bersifat khayali dan cenderung dengan fakta, realita, kronologis, dan sebagainya.

\section{Data (31)}

Sedangkan unsur ekstrinsik merupakan unsur yang mendukung karya sastra dari luar yang menyangkut aspek sosiologi, pisikologi, dan lain sebagainya.

\section{Data (33)}

Sedangkan pada bahasa prosa lebih menjurus kepada satu arti seperti yang dimaksudkan oleh pengarangnya.

\section{Data (34)}

Sedangkan novel tradisional, seperti epik, mempunyai dialog campuran, ada penyajian langsung, ada narasi.

\section{Data (35)}

Sedangkan puisi elegi dan iambic biasanya diiringi oleh seruling, dan puisi melic atau lirik diiringi oleh lira.

\section{Data (36)}

Sedangkan puisi-puisi utamanya adalah tragedi "biasa" dan dua epik.

\section{Data (37)}


Sedangkan kritikus-kritikus Renaisans secara konsisten memilih epik.

Data (38)

Sedangkan ciri sastra non- imajinatif adalah karya sastra yang lebih banyak unsur faktualnya daripada khayalinya, dan menggunakan bahasa yang cenderung denotative, dan memenuhi syarat-syarat estetika seni.

\section{Data (39)}

Sedangkan jenis drama terdiri dari drama komedi, drama tragedy, melodrama dan drama tragikomedi.

Data (19)-(39) ditemukan kalimatnya diawali oleh kata sedangkan, seolah-olah kalimat tersebut dapat berdiri sendiri. Kaidah yang berlaku tidak membenarkan penggunaan sedangkan untuk mengawali kalimat. Penggunaan sedangkan digunakan untuk menghubungkan antara dua kalimat atau lebih menjadi kalimat majemuk. Dapat dibandingkan dengan kalimat-kalimat berikut.

\section{Kalimat}

..., sedangkan untuk melakukan penelitian terhadap teater rakyat dapat menggunakan metodologi kajian tradisi lisan.

\section{Kalimat}

..., sedangkan sesuai dengan genrenya, sastra elektronik dapat dijabarkan ke dalam sub-sub genre seperti di bawah ini.

\section{b. Konjungsi karena}

Kalimatnya efektif

c. Konjungsi tetapi

Penggunaan konjungsi tetapi digunakan pada kalimat majemuk setara hubungan pertentangan, kedudukannya sama dengan konjungsi melainkan. Data berikut memperlihatkan penggunaan konjungsi tetapi pada awal kalimat.

\section{Data (40)}

Tetapi menurut beberapa aspek menunjukkan persamaan juga dengan kenyataan...

\section{Data (41)}

Tetapi yang secara teratur, menurut suatu hukum tertentu, selalu kembali.

\section{Data (42)}


Tetapi juga unsure yang menyangkut isi yang harus memberi motivasi bagi penyusunan cerita, dapat dianggap sebagai penyulapan.

\section{Data (43)}

Tetapi analisa tersebut dengan mudah dapat kita perluas dengan mengadakan perbandingan dengan aliran-aliran lain misalnya kode surrealistik yang dipakai Iwan Simatupang dalam kolong, misalnya.

\section{Data (44)}

Tetapi pada prinsipnya tidak ada perbedaan antara proses tak sadar pembaca awam dan proses sadar seorang ahli.

\section{Data (45)}

Tetapi tentang tradisi sastra didunia barat yang dominan dapat dikatakan bahwa secara ekspilit atau impilisit prinsip struktur koheren tadi dipertahankan...

\section{Data (46)}

Tetapi jawaban ini tidak secara adil memperhitungkan fakta perkembangan dan sejarah sastra.

\section{Data (47)}

Tetapi juga dalam dalam bentuk tulisan dan melahirkan sastra tulis.

Data tersebut dapat dibandingkan dengan kalimat

\section{Kalimat}

..., tetapi menurut beberapa aspek menunjukkan persamaan juga dengan kenyataan...

\section{Kalimat}

..., tetapi yang secara teratur, menurut suatu hukum tertentu, selalu kembali.

Penggunaan pasangan tidak-tetapi juga sering dipertukarkan dengan pasangan bukan-melainkan. Kalimat di atas diawali oleh konjungsi tetapi. Kaidah yang berlaku tidak membenarkan penggunaan tetapi untuk mengawali kalimat. Kalimat yang diawali dengan konjungsi tetapi menjadi tidak efektif, seolah-olah kalimat tersebut dapat berdiri sendiri. Dapat dibandingkan dengan data berikut.

\section{Data (48)}

Tapi paling tidak Aristoteles juga sadar akan adanya perbedaan mendasar lain antara drama, epik, dan lirik.

Data (49) 
Tapi kita bisa mengambil kesimpulan bahwa menurut pemikir-pemikir Neo-Klasik, pengertian genre sudah sedemikian jelasnya, sehingga bagi mereka tidak ada permasalahan umum sama sekali.

Data (50)

Tapi sebenarnya sastrawan hanya mampu memiliki ide-ide tentang realita tanpa memiliki kemampuan menangkap realita tersebut.

Data (51)

Tapi dalam menirukan realita, sebenarnya sastrawan terlibat dalam preses kreatif untuk menciptakan sesuatu berdasarkan realita yan ditanggapnya.

\section{Data (52)}

Tapi konsentrasinya justru pada perspektif kesadaran individu terhadap fenomena itu.

\section{Data (53)}

Tapi merambah ke sejarah, agama, politik, mitologi, ideology...

Data tersebut di atas dapat dibandingkan dengan kalimat

\section{Kalimat}

..., tetapi setidaknya Aristoteles juga menyadari perbedaan mendasar antara drama, epik, dan lirik.

\section{Kalimat}

..., tetapi dapat disimpulkan bahwa menurut pemikir-pemikir neo-klasik, pengertian genre sudah jelasnya sehingga tidak dipermasalahkan oleh mereka.

\section{d. Konjungsi sehingga}

Penggunaan sehingga digunakan untuk menghubungkan antara dua kalimat atau lebih menjadi kalimat majemuk. Penggunaan konjungsi sehingga digunakan pada kalimat majemuk hubungan akibat, kedudukannya sama dengan konjungsi hingga dan sampai.

\section{Data (54)}

Sehingga pemahaman tentang kurikulum/sistem pendidikan dan berbagai kebijakan dibidang pendidikan kurang konprehenship untuk dapat diimplementasikan dengan baik oleh tenaga kependidikan yang berada di sekolah-sekolah swasta.

\section{Data (55)}


Sehingga biasanya seorang yang berpendidikan tinggi lebih dapat mengendalikan sikap dan emosinya secara baik.

\section{Data (56)}

Sehingga, kelak anak akan menjadi anak yang unggul pada bidangnya masing-masing.

\section{Data (57)}

Sehingga ilmu pengetahuan dapat pula dibataskan sebagai sebuah sistem konsep pendidikan yang dihasilkan melalui riset.

\section{Data (58)}

Sehingga konsep memetiknya dikategorikan sebagai mimetic kreatif.

Data (60)

Sehingga tidak dapat dipisahkan antara satu dengan yang lainnya saling berurutan.

\section{Data (61)}

Sehingga bisa memberikan manfaat dan pengertian tentang sastra yang berguna bagi kita semua, khususnya dalam pembelajaran sastra.

Kalimat (54)-(61) diawali oleh kata sehingga. Kalimat yang diawali konjungsi sehingga menjadi tidak efektif, seolah-olah kalimat tersebut dapat berdiri sendiri. Kaidah yang berlaku tidak membenarkan penggunaan sehingga untuk mengawali kalimat. Dapat dibandingkan dengan kalimat-kalimat berikut.

\section{Kalimat}

...sehingga pemahaman tentang kurikulum sistem pendidikan dan berbagai kebijakan pada bidang pendidikan kurang komprehensif untuk dapat diimplementasikan dengan baik oleh tenaga kependidikan yang berada di sekolah-sekolah swasta.

\section{Kalimat}

... sehingga pada umumnya orang yang berpendidikan tinggi lebih dapat mengendalikan sikap dan emosinya dengan baik.

\section{e. Konjungsi dan}

Penggunaan dan digunakan untuk menghubungkan antara dua kalimat atau lebih menjadi kalimat majemuk. Penggunaan konjungsi dan digunakan pada kalimat majemuk setara penambahan, kedudukannya sama dengan konjungsi serta.

\section{Data (62)}


Dan ditemukan masalah-masalah pokok pendidikan, kaitan masalahmasalah pokok tersebut satu sama lain, faktor-faktor yang mempengaruhi perkembangannya, permasalahan pendidikan yang actual dan upaya penanggulangannya...

\section{Data (63)}

Dan penetapan angka 4,0 ini tidak dapat memberikan cukup energi bagi para praktisi untuk memacu kinerja dan meningkatkan kualitas proses pendidikan

\section{Data (64)}

Dan kenyataannya jumlah pungutan semakin besar dan jenisnya semakin banyak kepada orang yang sama, sehingga terjadi banyaknya keluhan orang tua siswa terhadap semakin tingginya biaya pendidikan anak.

\section{Data (63)}

Dan bagi yang tidak mampu lebih memilih sekolah swasta.

\section{Data (64)}

Dan karakteristik kata ini adalah samar, tidak akan pernah jelas.

\section{Data (65)}

Dan ketika Martin Luther menampilkan corak penafsiran barunya dalam gerakan reformasi agama bermucullah karya-karya seputar kaidah-kaidah penfsiran.

\section{Data (67)}

Dan pada abad XVIII corak penafsiran kitab suci betumpu pada filologi.

Kalimat (62)-(67) diawali oleh kata dan. Kalimat yang diawali konjungsi dan menjadi tidak efektif, seolah-olah kalimat tersebut dapat berdiri sendiri. Kaidah yang berlaku tidak membenarkan penggunaan dan untuk mengawali kalimat. Penggunaan dan digunakan untuk menghubungkan antara dua kalimat atau lebih, menjadi kalimat majemuk setara. Dapat pula dibandingkan dengan kalimat-kalimat berikut.

\section{Kalimat}

...dan ditemukan masalah-masalah pokok pendidikan, kaitan masalahmasalah pokok tersebut satu dengan yang lain, faktor-faktor yang memengaruhi perkembangannya, permasalahan pendidikan yang aktual dan upaya penanggulangannya...

\section{Kalimat}


...dan penetapan angka 4,0 ini tidak dapat memberikan semangat para praktisi untuk memacu kinerja dan meningkatkan kualitas proses pendidikan

\section{f. Konjungsi atau}

Kalimatnya efektif

\section{Kesejajaran unsur}

\section{Kehematan}

Penggunaan kata dan kalimat yang hemat merupakan salah satu ciri kalimat efektif. Kehematan dalam kalimat efektif meliputi penggunaan subjek yang tidak berulang, penghilangan bentuk ganda, dan penggunaan kata secara hemat. Berdasarkan penelitian yang telah dilakukan, ditemukan beberapa penggunaan kata dan kalimat yang berlebihan, penggunaan bentuk ganda, dan penggunaan konjungsi yang serentak.

\section{Kehematan Penggunaan Kata dan Kalimat}

a. Bentuk Jamak, kalimatnya efektif

b. Kalimat Panjang, kalimatnya efektif

\section{c. Bentuk frasa}

Frasa di mana sering digunakan bukan pada tempatnya. Frasa di mana sering dianalogikan penggunaannya dalam bahasa Inggris which dan where. Penggunaan frasa di mana tidak memberikan arti yang penting pada data berikut. Penggunaan frasa di mana sebaiknya dihilangkan saja karena tanpa kehadiran frasa di mana makna kalimat tetap dapat dipahami dan tetap gramatikal.

\section{Data (68)}

Dimana pengertian memberikan tuntunan telah tersimpul suatu dasar pengakuan bahwa anak (pihak yang diberi tuntunan) memiliki daya-daya (potensi) untuk dikembangkan.

\section{Data (69)}

Di mana di dalam puisi tersebut memiliki unsur-unsur yang membangun Data (70)

Karya sastra mempunyai dua unsur yaitu unsur ekstrinsik dan unsur intrinsik.Dimana pengertian unsur ekstrinsik adalah unsur yang membentuk karya sastra dari luar sastra.

\section{Data (71)}


Dimana unsur batin adalah suasana penyair dan unsur lahir adalah unsur bahannya yang digunakan dalam sebuah puisi.

\section{Data (72)}

Dimana aliran realisme jua aliran yang juga melukiskan orang-orang dan peristiwa-peristiwa dengan perasaan dan pemikiran-pemikirannya sampai kepada hal-hal terkecil dengan tidak memihak dan memberikan manifestasi jasmaniah (material) tanpa mempersoalkan sumbernya.

\section{Data (73)}

Sastra merupakan penghiburan, dimana karya sastra yang baik dan mampu memberi rasa puas dan rasa senang kepada pembacanya.

\section{Data (74)}

Dimana sastrawan menuliskan sastra sesuai dengan kenyataan atau fakta yang sebenarnya.

\section{Data (75)}

Dalam pembahasan ini jelas juga bahwa dalam dunia sastra dilukiskan banyak hal yang dalam kenyataan tidak pernah ada, dimana bila kita membaca teks-teks sastra, kita berhadapan dengan tokoh-tokoh dan situasi-situasi yang hanya terdapat dalam khayalan pengarang.

\section{Data (76)}

Karena ini merupakan tugas individu yang mana judul untuk pembahasannya telah ditentukan dosen pembimbing mata kuliah teori sastra.

Frasa di mana pada kalimat (68)-(76) membuat gagasan kalimat menjadi hilang karena fungsi frasa di mana menunjukkan pertanyaan sedangkan kalimat di atas tidak berfungsi membentuk kalimat tanya. Gejala-gejala tersebut mengakibatkan lemahnya struktur kalimat, mengganggu kebermaknaan dan kegramatikalan kalimat.

\section{d. Bentuk daripada}

Penggunaan daripada sering disamakan dengan penggunaan dari, dilihat sepintas dari dan daripada mirip tetapi maknanya berbeda seperti pada kalimat "Pakaiannya terbuat dari sutra dan gelas minumannya dari emas.", artinya bahannya berasal dari..., berbeda dengan kalimat "Hatinya bagaikan terbuat dari emas." Kalimat tersebut bermakna konotasi yang tidak dapat disamakan "Bahannya berasal dari..." 
Kata daripada digunakan untuk membandingkan sesuatu, misalnya "Lebih baik memudahkan urusan orang lain daripada menyulitkan urusannya.", artinya memudahkan urusan orang lain lebih baik dibandingkan menyulitkan urusan orang lain.

Kalimat-kalimat tersebut tidak dapat disubstitusi "Lebih baik memudahkan urusan orang lain dari menyulitkan urusannya." atau "Pakaiannya terbuat daripada sutra dan gelas minumannya daripada emas."

\section{Data (71)}

Profesionalisme diri merupakan hasil daripada suatu proses pemikiran profesional dan tindakan dalam pembelajaran sepanjang hayat.

\section{Bentuk Ganda}

\section{a. Bentuk adalah-merupakan}

Penggunaan pasangan adalah-merupakan mempunyai arti dan fungsi yang hampir sama sehingga kehadirannya yang serentak dalam sebuah kalimat dianggap berlebihan, seperti pada data berikut.

\section{Data (72)}

Walaupun fungsionalisme struktural memiliki banyak pemuka yang tidak selalu harus merupakan ahli-ahli pemikir teori, akan tetapi paham ini benar-benar berpendapat bahwa sosiologi adalah merupakan suatu studi tentang struktur-struktur sosial sebagai unit-unit yang terbentuk atas bagian-bagian yang saling tergantung.

Kalimat (72) di atas memperlihatkan kehadiran adalah dan merupakan yang serentak sehingga kalimat di atas menjadi berlebihan, sebaiknya apabila menggunakan adalah, jangan menggunakan merupakan. Konjungsi adalah dan merupakan digunakan untuk mendeskripsikan bagian yang lebih dahulu disebutkan pada sebuah kalimat. Posisi adalah dapat disubtitusikan dengan merupakan. Kalimat di atas selain berlebihan juga tidak gramatikal, makna kalimatnya berlebihan karena kehadiran adalah dan merupakan yang serentak. Dapat dibandingkan dengan kalimat-kalimat berikut.

\section{Kalimat}

Walaupun fungsionalisme struktural memiliki banyak pemuka yang tidak selalu harus merupakan ahli-ahli pemikir teori, paham ini benar-benar berpendapat bahwa sosiologi merupakan suatu studi tentang struktur- 
struktur sosial sebagai unit-unit yang terbentuk atas bagian-bagian yang saling tergantung.

\section{b. Bentuk hanya...saja}

Penggunaan bahasa sehari-hari kadang mengindahkan kaidah penggunaan pasangan hanya...saja. Lazimnya penggunaan pasangan ini menyebabkan pengguna bahasa tidak menyadari kekeliruannya. Kata hanya dan saja mempunyai arti dan fungsi yang hampir sama dalam sebuah kalimat sehingga kehadirannya yang serentak dalam sebuah kalimat dianggap berlebihan, seperti pada data berikut

\section{Data (73)}

Evaluasi yang kita lakukan kadang hanya mengambil aspek-aspek tertentu saja, misalnya aspek knowledgenya saja, sementara aspek afektif dan psikomotoriknya kita abaikan.

\section{Data (74)}

Komputer : yaitu hanya salah satu teknologi saja tetapi sulit untuk menghapus anggapan orang mengenai hal ini

\section{Data (75)}

...sebenarnya inti dari novel ini cukup baik hanya saja penceritaannya yang kurang bagus, yang dapat merusak moral, padahal dalam konpensi sastra telah di sepakati bersama bahwa tidak di perbolehkan menggunakan bahasa yang jorok.

\section{Data (76)}

Masih banyak hal yang tidak bisa didapatkan hanya dari pendidikan formal saja dan banyak faktor lain yang dapat mempengaruhi sikap mental dan cara / pola berpikir seorang individu disekolah.

Kalimat (73)-(76) memperlihatkan kehadiran hanya dan saja yang serentak sehingga kalimat di atas menjadi berlebihan, sebaiknya apabila menggunakan hanya, jangan menggunakan saja. Dapat dibandingkan dengan kalimat-kalimat berikut.

\section{Kalimat}

Evaluasi yang kita lakukan kadang hanya mengambil aspek-aspek tertentu, misalnya aspek knowledgenya, sedangkan aspek afektif dan psikomotorik diabaikan.

\section{Kalimat}

Komputer hanya salah satu teknologi, tetapi sulit untuk menghapus anggapan orang mengenai hal ini 


\section{c. Bentuk bertujuan untuk}

Kata bertujuan secara tersirat berarti untuk. Penggunaan pasangan bertujuan...untuk tergolong ungkapan yang berlebihan namun tidak sadari sebagai sesuatu yang berlebihan karena lazimnya penggunaan pasangan ini dalam kalimat, baik dalam kehidupan seharihari maupun dalam karya ilmiah seperti pada data berikut.

\section{Data (77)}

Berdasarkan perspektif kurikuler, pendidikan berwawasan global merupakan suatu proses pendidikan yang bertujuan untuk mempersiapkan tenaga terdidik kelas menengah dan profesional dengan meningkatkan kemampuan individu dalam memahami masyarakatnya dalam kaitan dengan kehidupan masyarakat dunia, dengan ciri-ciri:

\section{Data (78)}

Penulisan makalah ini bertujuan untuk memahami mengenai peningkatan kualitas mutu pendidikan mencakup masalah.

\section{Data (79)}

Pengadaan Buku Paket bertujuan untuk meningkatkan mutu pendidikan dengan cara meningkatkan produksi dan distribusi buku yang lebih bermutu, menjamin ketersediaannya di kelas serta pemanfaatannya secara maksimal oleh guru dan siswa.

\section{Data (80)}

Penulis makalah ini bertujuan untuk memenuhi tugas mid semester yang diberikan oleh dosen pembimbing mata kuliah Teori Sastra sebagai pengganti ujian mid semester, dengan judul "Genre Sastra".

\section{Data (81)}

Secara umum, pemulisan makalah ini bertujuan untuk memperkenalkan kepada pembaca mengenai unsur-unsur yang terdapat dalam karya sastra.

\section{Data (82)}

Jenjang pendidikan dasar bertujuan untuk menghasilkan lulusan yang memiliki dasar-dasar karakter, kecakapan, keterampilan, dan pengetahuan yang kuat dan memadai untuk mengembangkan potensi diri peserta didik secara optimal sehingga memiliki ketuhanan dan keberhasilan dalam pendidikan lanjutan atau dalam kehidupan yang selalu berubah sesuai dengan perkembangan jaman.

\section{Data (83)}


Sebagai lanjutan dari jenjang pendidikan dasar, penyelenggaraan pendidikan menengah bertujuan untuk menghasilkan lulusan yang memiliki karakter, kecakapan, keterampilan, dan pengetahuan yang kuat untuk kemudian digunakan dalam mengadakan hubungan timbal balik dengan lingkungan sosial, budaya, dan alam sekitar serta mengembangkan kemampuan lebih lanjut dalam dunia kerja atau pendidikan tinggi.

\section{Data (84)}

Pendidikan bertujuan untuk meningkatkan kualitas sumber daya manusia.

Kalimat (77)-(84) memperlihatkan kehadiran bertujuan dan untuk yang serentak sehingga kalimat di atas menjadi berlebihan, sebaliknya apabila menggunakan bertujuan, jangan menggunakan untuk. Dapat dibandingkan dengan kalimat-kalimat berikut.

\section{Kalimat}

Berdasarkan perspektif kurikuler, pendidikan berwawasan global merupakan suatu proses pendidikan yang bertujuan mempersiapkan tenaga terdidik kelas menengah dan profesional dengan meningkatkan kemampuan individu dalam memahami masyarakatnya dalam kaitan dengan kehidupan masyarakat dunia, dengan ciri-ciri:

\section{Kalimat}

Penulisan makalah ini bertujuan memahami peningkatan kualitas mutu pendidikan mencakup masalah...

\section{Kehematan Konjungsi}

\section{a. Pasangan jika-maka}

Penggunaan dua kata penghubung penanda anak kalimat yang melekat pada kalimat sebelah kiri dan sebelah kanan sudah umum digunakan sehingga dirasakan bukan lagi hal yang rancu. Hal itu harus mendapat perhatian serius. Dapat dilihat pada data berikut.

\section{Data (85)}

Jika konflik itu tidak wajar dan tidak kuat, maka jalan ceritanya akan datar dan tidak menimbulkan daya tarik.

\section{Data (86)}


Jika posisinya sudah nampak tidak seimbang, maka konflik menjadi tidak wajar karena pembaca segera akan menebak kelanjutan jaln ceritanya.

\section{Data (87)}

Jika disebut dalam novel jenis ini maka penggambarannya hamper stereotif dan kurang berperan.

\section{Data (88)}

Jika wanita disebut dalam novel jenis ini, maka penggambarannya hampir stereotif dan kurang berperan

\section{Data (89)}

Jika hal ini dibiarkan terus, maka akan timbul bahkan sudah terjadi sikap apatis yang akan mmenmnatikan semangat dari sekolah atau swasta untuk mahu dan mampu berkompetisi dalam sekolah negeri secara berkeadilan

\section{Data (90)}

Jika kita melihat dari jenis kurikulum yang telah diterapkan, maka secara garis besar bahwa ke lima komponen diatas pada dasarnya sudah ada disetiap kurikulum yang pernah diterapkan dalam dunia pendidikandi Indonesia

Data (91)

Jika suatu objek di konkritkan dalam karya oleh orang yang berbeda, maka akan melahirkan bentuk yang berbeda pula.

Kalimat (85)-(91) memperlihatkan kehadiran konjungsi penanda anak kalimat pada kalimat sebelah kiri dan kanan sehingga kalimatkalimat tersebut tidak memiliki induk kalimat. Kalimat tersebut merupakan kalimat panjang yang terdiri dua anak kalimat tanpa induk sehingga gabungan kedua kalimat tersebut tidak menghasilkan kalimat majemuk.

Bandingkan dengan kalimat berikut. Kalimat tersebut sudah dapat ditemukan induk dan anak kalimatnya.

\section{Kalimat}

Jika konflik itu tidak wajar dan tidak kuat, jalan ceritanya akan datar dan tidak menimbulkan daya tarik.

\section{Kalimat}

Jika posisinya sudah tampak tidak seimbang, konflik menjadi tidak wajar karena pembaca segera akan menebak kelanjutan jalan ceritanya. 


\section{b. Pasangan kalau-maka}

Penggunaan dua kata penghubung penanda anak kalimat yang melekat pada kalimat sebelah kiri dan sebelah kanan sudah umum digunakan sehingga dirasakan bukan lagi hal yang rancu. Hal itu harus mendapat perhatian serius. Dapat dilihat pada data berikut.

\section{Data (92)}

Kalau dalam karya sastra unsur khayali agak berkurang dan penggunaan bahasa cenderung denotatif, maka karya demikian cenderung digolongkan ke dalam karya sastra non imajinatif.

\section{Data (93)}

Kalau Schleler Marcher tantangannya adalah Hegelisme dan Feurbaghisme, maka Dilthey adalah ilmu Fisika di satu sisi dan filsafat idealisme di sisi lain.

\section{Data (94)}

Kalau semiotika bercirikan teks yang formil dan sederhana, maka hermeneutika lebih jauh dan lebih dalam dari pada itu, yaitu kedalaman makna.

\section{Data (95)}

Dan kalau dekonstruksi Michel Foucoult memporak porandakan makna suatu teks, maka hermeneutika justru mencari nilai terdalam yang terkandung dalam teks.

\section{Data (96)}

Kalau dalam sebuah karya sastra unsure khayali agak berkurang dan penggunaan bahasa cenderung denotative, maka karya demikian cenderung digolongkan ke dalam karya sastra non-imajinatif.

Kalimat (92)-(96) memperlihatkan kehadiran konjungsi penanda anak kalimat pada kalimat sebelah kiri dan kanan sehingga kalimatkalimat tersebut tidak memiliki induk kalimat. Kalimat tersebut merupakan kalimat panjang yang terdiri dua anak kalimat tanpa induk sehingga gabungan kedua kalimat tersebut tidak menghasilkan kalimat majemuk.

Bandingkan dengan kalimat berikut. Kalimat tersebut sudah dapat ditemukan induk dan anak kalimatnya.

\section{Kalimat}


Jika dalam karya sastra unsur khayali agak berkurang dan penggunaan bahasa cenderung denotatif, karya demikian cenderung digolongkan ke dalam karya sastra nonimajinatif.

\section{Kalimat}

Schleler Marcher tantangannya adalah Hegelisme dan Feurbaghisme, sedangkan Dilthey tantangannya adalah ilmu Fisika di satu sisi dan filsafat idealisme di sisi lain.

\section{c. Pasangan apabila/bila-maka}

Penggunaan dua kata penghubung penanda anak kalimat yang melekat pada kalimat sebelah kiri dan sebelah kanan sudah umum digunakan sehingga dirasakan bukan lagi hal yang rancu. Hal itu harus mendapat perhatian serius. Dapat dilihat pada data berikut.

\section{Data (97)}

Apabila ini bisa diterapkan disetiap jenjang satuan pendidikan maka kekerasan di dunia pendidikan tidak akan terjadi

\section{Data (98)}

Oleh sebab itu, apabila garapan pendidikan ingin dilaksanakan secara terencana dan teratur, maka berbagai faktor yang terlibat dalam pendidikan harus dipahami terlebih dahulu.

\section{Data (99)}

Apabila realitas itu adalah sebuah peristiwa sejarah, maka karya sastra dapat mencoba menerjemahkan peristiwa itu dalam bahasa imajiner dengan maksud untuk memahami peristiwa sejarah menurut kadar kemampuan pengarang

\section{Data (100)}

Bila kita mengetahui fakta tentang ras, momen, dan lingkungan, maka kita dapat memahami iklim rohani suatu kebudayaan yang melahirkan seorang pengarang beserta karyanya.

\section{Data (101)}

Bila kita menganalisa sebuah maka sebetulnya kita dapat menentukan berapa kode yang ingin atau harus kita pelajari sambil menganalisa karya yang bersangkutan.

Kalimat (97)-(101) memperlihatkan kehadiran konjungsi penanda anak kalimat pada kalimat sebelah kiri dan kanan sehingga kalimat-kalimat tersebut tidak memiliki induk kalimat. Kalimat tersebut 
merupakan kalimat panjang yang terdiri dua anak kalimat tanpa induk sehingga gabungan kedua kalimat tersebut tidak menghasilkan kalimat majemuk.

Bandingkan dengan kalimat berikut. Kalimat tersebut sudah dapat ditemukan induk dan anak kalimatnya.

\section{Kalimat}

Apabila ini dapat diterapkan pada setiap jenjang satuan pendidikan, kekerasan di dunia pendidikan tidak akan terjadi

\section{Kalimat}

Oleh sebab itu, apabila proses pendidikan ingin dilaksanakan secara terencana dan teratur, berbagai faktor yang terlibat dalam pendidikan harus dipahami terlebih dahulu.

\section{d. Pasangan ketika-maka}

Kalimatnya efektif

\section{e. Pasangan karena-maka}

Penggunaan dua kata penghubung penanda anak kalimat yang melekat pada kalimat sebelah kiri dan sebelah kanan sudah umum digunakan sehingga dirasakan bukan lagi hal yang rancu. Hal itu harus mendapat perhatian serius. Dapat dilihat pada data berikut.

\section{Data (102)}

Karena setiap genre mempunyai fungsi sosial yang berbeda maka setiap genremempunyai tahapan atau struktur skematik (struktur awal - struktur inti - dan struktur akhir) yang berbeda-beda.

\section{Data (103)}

Karena pembahasan tentang sastra dalam makalah ini sangat terbatas, maka bagi pembaca yang menyukai tentang sastra ini dapat memperdalamnya dengan mempelajari dari buku-buku sastra yang lain sebagai referensi.

\section{Data (104)}

Karena pembelajaran bahasa pada hakikatnya adalah pembelajaran budaya, maka guru perlu memahami budaya peserta didik, dengan tidak melupakan tujuan pengajaran, yang salah satunya adalah menghargai dan membanggakan sastra Indonesia sebagai khazanah budaya dan intelektual manusia Indonesia

\section{Data (105)}


Karena sastra tidak bisa di pisahkan dengan bahasa maka saya berpendapat bahwa sastra itu tercipta semenjak manusia tercipta boleh di katakan manusia dan sastra tercipta dengan bersamaan.

\section{Data (106)}

Sebagai bukti, karena hasil pembangunan ekonomi tidak bisa dibagi secara merata, maka konsekuensinya kesempatan untuk mendapatkan pendidikan tidak juga bisa sama di antara berbagai kelompok masyarakat, sebagaimana terjadi dewasa ini.

Kalimat (102)-(106) memperlihatkan kehadiran konjungsi penanda anak kalimat pada kalimat sebelah kiri dan kanan sehingga kalimat-kalimat tersebut tidak memiliki induk kalimat. Kalimat tersebut merupakan kalimat panjang yang terdiri dua anak kalimat tanpa induk sehingga gabungan kedua kalimat tersebut tidak menghasilkan kalimat majemuk.

Bandingkan dengan kalimat berikut. Kalimat tersebut sudah dapat ditemukan induk dan anak kalimatnya.

\section{Kalimat}

Karena setiap genre mempunyai fungsi sosial yang berbeda, setiap genre mempunyai tahapan atau struktur skematik (struktur awal - struktur inti dan struktur akhir) yang berbeda-beda

\section{Kalimat}

Karena pembahasan tentang sastra dalam makalah ini sangat terbatas, pembaca yang menyukai sastra ini dapat memperdalamnya dengan mempelajari buku-buku sastra yang lain sebagai referensi.

\section{f. Pasangan karena-sehingga}

Kalimatnya efektif.

\section{g. Pasangan walaupun-tetapi}

Kalimatnya efektif.

\section{h. Kalau-maka}

Penggunaan dua kata penghubung penanda anak kalimat yang melekat pada kalimat sebelah kiri dan sebelah kanan sudah umum digunakan sehingga dirasakan bukan lagi hal yang rancu. Hal itu harus mendapat perhatian serius. Dapat dilihat pada data berikut.

\section{Data (107)}


Kalau dalam karya sastra unsur khayali agak berkurang dan penggunaan bahasa cenderung denotatif, maka karya demikian cenderung digolongkan ke dalam karya sastra non imajinatif.

\section{Data (108)}

Kalau Schleler Marcher tantangannya adalah Hegelisme dan Feurbaghisme, maka Dilthey adalah ilmu Fisika di satu sisi dan filsafat idealisme di sisi lain.

\section{Data (109)}

Kalau semiotika bercirikan teks yang formil dan sederhana, maka hermeneutika lebih jauh dan lebih dalam dari pada itu, yaitu kedalaman makna.

\section{Data (110)}

Dan kalau dekonstruksi Michel Foucoult memporak porandakan makna suatu teks, maka hermeneutika justru mencari nilai terdalam yang terkandung dalam teks.

\section{Data (111)}

Kalau dalam sebuah karya sastra unsure khayali agak berkurang dan penggunaan bahasa cenderung denotative, maka karya demikian cenderung digolongkan ke dalam karya sastra non-imajinatif.

Kalimat (107)-(111) memperlihatkan kehadiran konjungsi penanda anak kalimat pada kalimat sebelah kiri dan kanan sehingga kalimat-kalimat tersebut tidak memiliki induk kalimat. Kalimat tersebut merupakan kalimat panjang yang terdiri dua anak kalimat tanpa induk sehingga gabungan kedua kalimat tersebut tidak menghasilkan kalimat majemuk.

Bandingkan dengan kalimat berikut. Kalimat tersebut sudah dapat ditemukan induk dan anak kalimatnya.

\section{Kalimat}

Jika dalam karya sastra unsur khayali agak berkurang dan penggunaan bahasa cenderung denotatif, karya demikian cenderung digolongkan ke dalam karya sastra non imajinatif.

\section{Kalimat}

Schleler Marcher tantangannya adalah Hegelisme dan Feurbaghisme, sedangkan Dilthey tantangannya adalah ilmu Fisika di satu sisi dan filsafat idealisme di sisi lain. 


\section{SIMPULAN DAN SARAN}

Terdapat 44 kalimat yang tidak efektif ditinjau dari kehematan penggunaan kalimatnya meliputi kehematan kata, bentuk ganda, dan konjungsi. Kalimat yang tidak efektif tersebut berupa (a) kehematan kata, bentuk frasa di mana, adalah, dari, daripada, (b) penggunaan bentuk ganda, seperti adalah-meruapakan, hanya...saja, bertujuan untuk, (c) kehematan konjungsi seperti pasangan jika-maka, kalau-maka, apabila/bila-maka, karena maka. Terdapat 57 kalimat yang tidak efektif dalam makalah ditinjau dario kesejajaran bentuk berupa (a) kesejajaran unsur, (b) kesejajaran pasangan konjungsi, dan (c) kesejajaran penyusunan kalimat. Sebaiknya diadakan pelatihan pembuatan makalah, baik untuk mahasiswa maupun dosen, pelatihan penulisan karya tulis ilmiah lebih diintensifkan dan jika perlu semua mahasiswa baru diwajibkan mengikuti matrikulasi penulisan ilmiah.

\section{DAFTAR PUSTAKA}

Alwi, Hasan (ed). 1993. Tata Bahasa Baku Bahasa Indonesia. Jakarta: Balai Pustaka.

. 2001. Kalimat. Jakarta: Pusat Bahasa Departemen Pendidikan Nasional.

Amir, Amriani. 2001. "Tinjauan Bahasa: Mampukah Mencegah Gejala Disintegrasi dan Menjadikannya sebagai Alat Integratif'. Makalah. Makassar: Forum Komunikasi Nasional.

. 2002. "Ragam Bahasa Paramedis". Skripsi. Makassar: Fakultas Sastra Unhas.

. 2005. "Penggunaan Kalimat dalam Naskah Disertasi Mahasiwa Program Pascasarjana Universitas Hasanuddin Makasar". Tesis. Makassar: Pascasarjana Unhas.

Arifin, Zaenal. 1991. 1001 Kesalahan Berbahasa. Jakarta: Akademika Pressindo.

Arikunto, Suharsimi. 1992. Prosedur Penelitian. Jakarta: PT Melton Putra.

Akhadiah, Sabarti dkk. 1996. Pembinaan Kemampuan Menulis Bahasa Indonesia. Jakarta: Penerbit Erlangga. 
Badudu, J. S. 1982. Pelik-pelik Bahasa Indonesia. Bandung: Pustaka Prima.

Badudu, Rabianah dkk. (tanpa tahun). "Materi Pelajaran Sintaksis Bahasa Indonesia". Makassar: Fakultas Sastra Unhas.

Darwis, Muhammad. 2002. "Masa Depan Bahasa Indonesia sebagai Bahasa Pemersatu". Makalah. Makassar: Seminar bulan bahasa dan ulang tahun Fakultas Sastra.

Hakim, Wahyuddin. 1997. "Pilihan Kata dalam Karya Tulis Ilmiah". 1997. Tesis. Makassar: Program Pascasarjana Universitas Hasanuddin.

Halim, Amran. 1979: Pembinaan Bahasa Nasional. Jakarta: Pusat Pembinaan dan Pengembangan Bahasa Pendidikan dan Kebudayaan.

Hastuti, Sri. 2003. Sekitar Analisis Kesalahan Berbahasa Indonesia. Yogyakarta: Mitra Gama Widya.

Moeliono, M. A. 1985. Pengembangan dan Pembinaan Bahasa. Jakarta: Djambatan.

.: 1998. Bahasa Indonesia Menjelang Tahun 2000: Risalah Kongres Bahasa Indonesia VI. Jakarta: Pusat Pembinaan dan Pengembangan Bahasa Departemen Pendidikan dan Kebudayaan.

Nababan. 1984. Sosiolinguistik. Jakarta: Gramedia.

Program Pascasarjana Universitas Hasanuddin. 2005. Makassar: Pedoman Penulisan Tesis dan Disertasi.

Robert, Paul. 1964. English Syntax. New York: Harcourt Brase \& World Inc.

Sugono, Dendy. 1995. Pelesapan Subjek dalam Bahasa Indonesia. Jakarta: Pusat Pembinaan dan Pengembangan Bahasa. . 1997. Berbahasa Indonesia dengan Benar. Jakarta: Puspa Swara.

Suwito. 1983: . Sosiolinguistik:Suatu Pengantar. Bandung: Angkasa. 